\title{
EVALUATION OF LOCAL ECONOMIC ACTIVITIES AS ELEMENTS OF THE DEVELOPMENT OF SMALL AND MEDIUM-SIZED CITIES*
}

\author{
OCENA LOKALNYCH AKTYWNOŚCI EKONOMICZNYCH \\ JAKO ELEMENT ROZWOJU MAŁYCH I ŚREDNICH MIAST
}

https://doi.org/10.34739/zn.2020.53.05

\author{
Daniel Budzeńn ${ }^{1}$, Andrzej Sobczyk ${ }^{2}$ \\ ${ }^{1}$ Poland, Gniezno College Milenium \\ daniel.budzen@milenium.edu.pl; ORCID: 0000-0003-0895-6181 \\ 2 Poland, West Pomeranian University of Technology, Szczecin, Faculty of Economics \\ andrzej.sobczyk@zut.edu.pl; ORCID: 0000-0002-3235-4407
}

JEL Classification Codes: H23, O18, R11

\begin{abstract}
The concept of local development factors has gained in importance in the context of the reduction of existing resources, especially financial ones. The purpose of the present study is to evaluate localized economic activity as an endogenous factor in the development of small and medium-sized cities. Therefore, the individual sources of income of residents were examined on the basis of the data submitted with their tax declarations. The study covered the years 2016-2018, and included 255 small and medium-sized Polish cities that are revealing a depletion of their socio-economic functions. In order to assess local economic activities, the normalization method was used to compare the cities in terms of their potential. The results thus obtained allow for conclusions to be drawn on the importance of various sources of revenue to the development of cities, and are complementary to the analyses carried out so far in this area.
\end{abstract}

Keywords: residents' economic activity, local development, local government unit, economic potential

Streszczenie: Pojęcie czynników rozwoju lokalnego nabiera znaczenia w kontekście ograniczenia dotychczasowych zasobów, zwłaszcza finansowych. Celem niniejszego opracowania jest ocena aktywności ekonomicznej mieszkańców, jako endogennego czynnika rozwoju małych i średnich miast. Z tego względu badaniu zostały poddane poszczególne źródła dochodów mieszkańców na podstawie danych wynikających ze składanych deklaracji podatkowych. Okres badawczy dotyczy lat 2016-2018 i obejmuje 255 małych i średnich miast w Polsce tracących swoje funkcje społeczno-gospodarcze. W celu przeprowadzenia oceny lokalnych aktywności ekonomicznych zostanie wykorzystana metoda normalizacji, która pozwoli dokonać porównania potencjału miast. Uzyskane wyniki pozwalają na sformułowanie wniosków o znaczeniu poszczególnych źródeł dochodów dla rozwoju miasta, a także stanowią uzupełnienie dotychczas prowadzonych analiz w przedmiotowym zagadnieniu.

Słowa kluczowe: aktywność ekonomiczna mieszkańców, rozwój lokalny, jednostka samorządu terytorialnego, potencjał gospodarczy

* This publication was prepared under the research topic "Supporting regional development by monitoring the socio-economic situation", pursued by the Department of System Analysis and Marketing, Faculty of Economics, West Pomeranian University of Technology, Szczecin, Poland.

\section{Introduction}

The problems of local development have long been of interest to researchers. It is worth paying attention to the considerations conducted by $\mathrm{L}$. Batagan, E. Ostrom (2000), G. Swinburn, S. Goga and F. Murphy (2006), E. Zavadskas, M. Viteikiene, J. Saparauskas (2007), Śleszyński (2016). The development potential of a local government unit is not dependent solely on the available sources of financing or an efficient management of public funds and assets. Local development is also facilitated by the endogenous sources of potential for development. R. Stimson, R. Stough and M. Salazar $(2005$, p. 49) indicate in their research that the development of cities is strongly dependent on endogenous factors such as leadership, institutionalization and entrepreneurship. 
The information used for the first time to show the sources of income of residents allows for an evaluation of local economic activities, which is the main objective of this paper. The collected empirical data pertains to the specific forms of the residents' local economic activity, such as, inter alia, income from employment contracts, mandate contracts or contracts for specific work, old-age and disability pensions, and non-agricultural business activity. The research sample was selected using the delineation methodology developed by P. Śleszyński (2016), which applies to small and medium-sized cities losing their former socio-economic functions. These cities are characterized by a decrease in socio-economic importance in relations to the environment, as well as the deepening of differences in development.

\section{Economic activity of residents as an endogenous source of urban socio-economic development - review of literature}

Currently, research into urban development, as well as the structure and socio-economic situation of cities, has become a popular trend. An example is the research and considerations carried out by D. Hoornweg and M. Freire (2013), A. Gruszecka-Tieśluk (2013), P. Śleszyński (2016).

The development of small and medium-sized cities depends on the existing socio-economic ties. One of the reasons for economic growth and socio-economic development is the level of integration with the local environment (in the field of regional and local space, tourism, housing, economic relations with the rural area). There are cities that are strongly or poorly integrated, as well as cities that do not use their development opportunities (Heffner, 2016, p. 16).

The dynamic changes affecting the socioeconomic reality, including the demographic processes modifying the structure of the population, have led to a need to identify further factors affecting urban development. Therefore, it is not only the specificity of the local population, but also its economic activity and the city's professional structure and job diversity, that gain in significance (Sadowy, 2019, p. 23).

At this point, the creative class theory, also referred to as the creative capital theory, should be invoked. The idea is that the so-called creative class is one of the factors determining the broadly defined development of cities. It includes, inter alia, employees working in innovative and creative industries. This group includes IT professionals, management experts and law professionals. These are the professions that attract high-tech and fast-growing businesses. In addition to attracting the technology industry, the creative class can also be credited with causing economic growth (Pratt, 2008, p. 108).

Considering the ramifications of Economic Base theory, which refers largely to the impact of the exogenous sector resulting in a faster development of the city's functions that determine its specialization, we may observe the endogenous aspect of urban functions. But due to the specializing effect on the city's unique features, these same exogenous activities are found to be more impactful (Matczak and Szymańska, 2000, p. 97-98).

The impulses for the development of the city are provided by the exogenous sector, triggering the multiplier effect. This is reflected in the fact that an increase in the range of the territorial impact of the city's specialization results in higher revenues, available to be used for developing the city. An increased demand for services and products stemming from the city's endogenous function will be an additional effect (Sokołowski, 2008, p. 246). This increase in the city's own revenues is part of the financial policy that is taken into account in the local development plans. The sources of funding for such undertakings occupy a special position in this area. Therefore, an urban potential analysis should also account for, inter alia, the absorption capacity of the exogenous resources and the investment potential (Budzeń, 2018, p. 50).

The endogenous potential for the development of cities saw its acme at the end of the 20th century, pertaining in particular to the development of the territory; which should also take into account the available resources. It was visible through the amelioration of the local autonomy, which can be understood as the freedom to choose projects and resources in order to implement them (Jewtuchowicz, 2016, p. 223).

In the light of these considerations, the work of E. Ostrom, who explored common resource efficiency in local community management processes, is worth taking note of. The resource system is perceived as a collection of either natural or man-made resources. From this point of view, it is also important to distinguish between the producers of resources, those who supply them, and those who exploit them. According to this concept, attention should be paid to the relationships between the resource producers and users. It is therefore necessary to have a public institution supporting the market and monitoring the level of the city's endogenous resources (Faller, 2009, p. 4-7).

The evolution of social standards is one of the factors influencing common resource efficiency. This is linked to a collective action problem, where 
irrational behavior may lead to inefficient use of the resources held (Ostrom, 2000, p. 154).

In the context of the urban development theory, approaches concentrating on the efficiency of public tasks, also in the context of institutional efficiency, should be taken into account. Research confirms that the economic policies and the actions undertaken by public authorities stimulate economic processes. As a consequence of that, the infrastructure designed to support innovative enterprises is not used in accordance with the initial mission and vision (Bąkowski, 2018, p. 6-10).

A. Drobniak notes that the emergence of new innovative products has resulted in an increase in consumer income. The result is development of the services the demand for which is satisfied by the commercial sector (2016, p. 31).

The economic activity of the residents is one of the endogenous factors of urban development. The source literature generally considers this area through the prism of the level and structure of employment, the number of economic operators, the professional activity of the residents, the subsidies obtained from various sources by the local authorities, and the civic participation of the residents, e.g. their participation in the general elections (Łapczyński, 2005, p. 79-80).

Further on in the present paper, the residents' economic activity will be analyzed through the prism of, inter alia, the income gained by the local community. This approach should provide a complement to the economic base theory and the research performed by E. Ostrom into analyses of the economic aspects of management by local communities. The income made by residents is characterized by uncertainty, which is linked to the unpredictability of social behaviors with regard to employment and the economic activities undertaken.

\section{Objective, study group, temporal scope of the study and the data source}

The objective of the empirical study was to evaluate the residents' economic activity in small and medium-sized cities. Considering the existing research into this subject, the decision was made to examine the following categories: the number of taxpayers (including their structure with regard to the sources of income), the structure of the taxpayers' income according to the source of income, and the value of the average income according to the sources. A detailed examination procedure will be further specified later on in the article. The temporal scope covered the years 2016-2018, and was dictated by source data availability.

The data used for the present study were obtained from the Finance Ministry (the POLTAX system) and presented using the Association of Polish Cities' IT tool designed for in-depth analyses. Importantly, these data were published for the first time, and hence no detailed analysis of information on the sources of the residents' income was possible. For this reason, the present study is a novelty and generates value added, and as such complements the existing theories dealing with the economic analysis of urban development.

According to the authors, the residents' income potential is one of the key endogenous factors of urban development. In order to be able to draw conclusions, the efficiency of the individual sources of the residents' income had to be identified. Efficiency of the sources of income is defined as the ratio of income from the given source to the number of taxpayers making income from that source. The higher the value per taxpayer, the higher the efficiency.

The study group included 255 small and mediumsized Polish cities that were losing their socioeconomic potential according to the delineation methodology developed by P. Śleszyński ${ }^{4}$. This group of cities were characterized by unfavorable trends, both with regard to their socio-economic significance and the relationships between the cities and their environment. A marked increase in disparities and, consequently, the exacerbation of their development problems related to decreasing population (of the well-educated and entrepreneurial circles), aging society and a worsening labor market situation, as well as challenges related to social inclusion and communication accessibility, were being observed. Moreover, the selected cities demonstrated the inefficient use of economic resources (Śleszyński, 2016, p. 2).

For this reason, the study also aimed to identify the key endogenous factors of the socio-economic development of the city. As already mentioned, the endogenous resources affecting urban development include the economic activity of the residents. Therefore, both the income generated by the population and its sources were of significance for the purposes of the study. Apart from this, this sort of information is also of major importance to public authorities which, by gaining knowledge of what their residents' endogenous economic resources are, can effectively manage all circumstances relating to socio-economic development.

\footnotetext{
${ }^{4} \mathrm{~A}$ list of the cities included in the study group can be found in a paper written for the purposes of the Strategy for Responsible Development (Śleszyński, 2016, p. 26-30).
} 
For the purposes of the study, it was hypothesized that the residents' economic activity in the form of non-agricultural business activity was the most efficient source of income. A research procedure is proposed later in the paper to identify the sources of the population's economic activity and to classify the cities based on the criterion of the most efficient source of income.

\section{Results}

The taxpayers' income from all sources, as declared in their annual tax statements PIT-36, PIT-37, PIT-40 and PIT-28, was analyzed. Persons making income from employment relationships were by far the largest group within the total taxpayer structure. Similarly, the value of income from employment contracts was predominant within the total income structure. Over the period in question, the structure values maintained their levels.

A comparison between the quantitative structure of taxpayers and the structure of income by source of income (Fig. 1) shows that more than $60 \%$ of the total income was generated under employment contracts by almost half of the taxpayers; but, importantly, nearly $20 \%$ of the total income was generated from business activity by less than $7 \%$ of all taxable persons.

This may be evidence for the efficiency of nonagricultural business activity as a source of income. In order to confirm the proposed conclusion, the sources of income are shown in terms of their value per taxable person. Here, this ratio reaches its highest value for business activity. At the same time, the increase in average income from business activity is the highest of all sources over the period under consideration.

Further analysis focused on the average income from business activity. These values were accepted as a diagnostic variable. The descriptive parameters of the analyzed variable are listed in Table 1. The coefficient of variation proved to be low (less than 25\%), which indicated a high uniformity of the urban population under study. The variable was positively skewed, which means that most of the results for the cities were below the average.

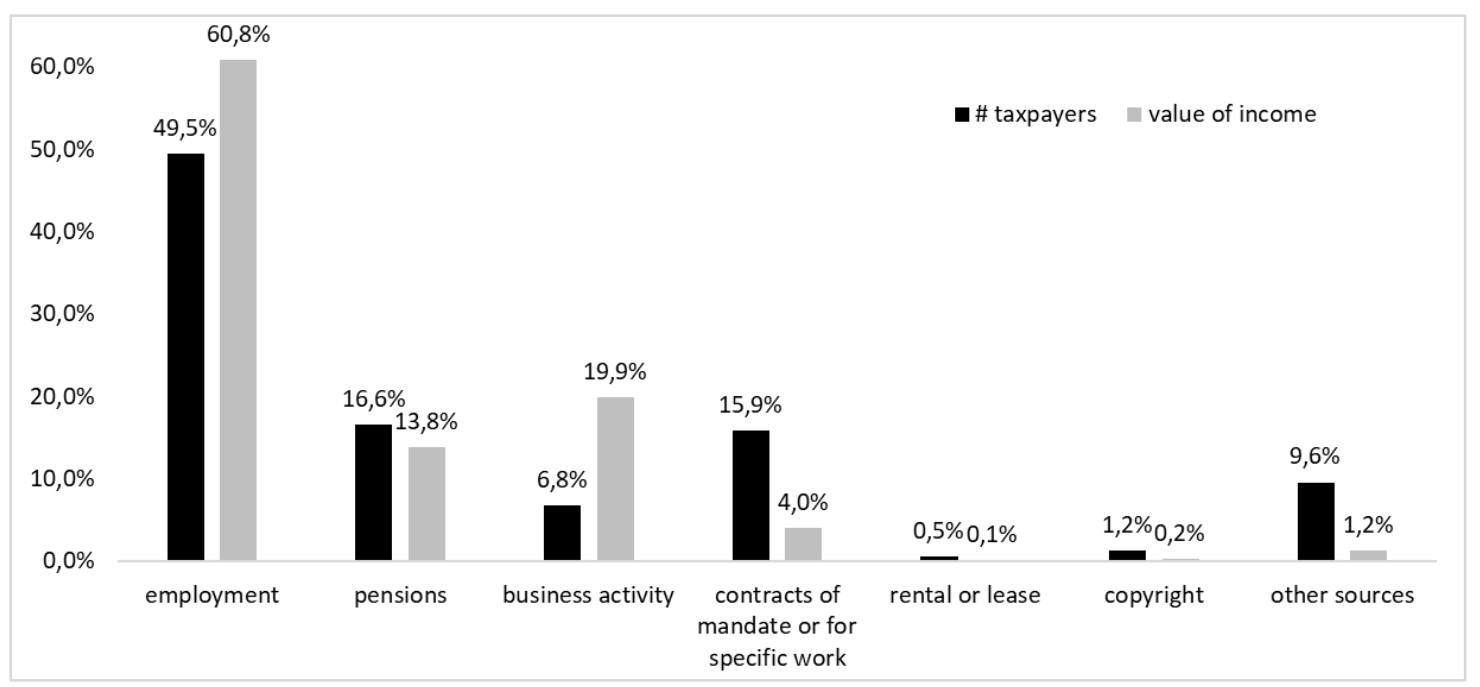

Figure 1. Comparison of the quantitative structure of taxable persons and the income structure by source of income in 2018 Source: developed by the author.

Table 1. Descriptive parameters of the diagnostic variable - average income of taxable persons from business activity

\begin{tabular}{lrrr}
\hline & $\mathbf{2 0 1 6}$ & $\mathbf{2 0 1 7}$ & $\mathbf{2 0 1 8}$ \\
\hline Max & $151,041.82$ & $167,075.27$ & $196,539.35$ \\
Min & $53,198.65$ & $59,323.22$ & $64,129.56$ \\
standard deviation & $14,631.83$ & $16,568.41$ & $19,245.84$ \\
Median & $81,663.91$ & $89,396.35$ & $101,149.60$ \\
Mean & $82,889.09$ & $91,700.41$ & $104,478.67$ \\
Skewness & 0.897 & 0.885 & 1.139 \\
coefficient of variation & 0.177 & 0.181 & 0.184 \\
\hline
\end{tabular}

Source: developed by the author. 
In order to determine the differences between cities characterized by different potential in terms of the income that taxpayers achieve from their business activities, the units were ranked using the linear ordering method. A normalization method was used to achieve mutual comparability, and the results were presented by means of a synthetic measure. The standardized variables ij were calculated based on the formula for the stimulant:

$$
z_{i j}=\frac{x_{i j}-x_{i j}}{x_{i j}-x_{i j}} ; \quad x_{i j} \neq x_{i j}
$$

The values of the measure range between 0 and 1 , where 0 is the worst result and +1 is the best. The diagnostic variable was made comparable, and then expressed by the mean on a point scale of $<0 ; 100\rangle$. The descriptive parameters of the synthetic variable are listed in Table 2.

The calculated values of the synthetic variable were the basis for classifying the cities into typological groups similar in terms of the potential of their income from business activity. The division was based on the mean and the standard deviation of the synthetic variable, and four groups of cities were created according to the formulae in Table 3.

Table 2. Variable normalization - synthetic variable, descriptive parameters

\begin{tabular}{lrrr}
\hline & $\mathbf{2 0 1 6}$ & $\mathbf{2 0 1 7}$ & $\mathbf{2 0 1 8}$ \\
\hline Mean & 30.34 & 30.05 & 30.47 \\
standard deviation & 14.95 & 15.38 & 14.54 \\
coefficient of variation & 0.49 & 0.51 & 0.48 \\
Skewness & 0.90 & 0.89 & 1.14 \\
\hline
\end{tabular}

Source: developed by the author.

Table 3. City classification ranges

\begin{tabular}{cll} 
Group & $\begin{array}{c}\text { Classification } \\
\text { range }\end{array}$ & \multicolumn{1}{c}{ Level of potential } \\
\hline 1 & $q_{i} \geq \underline{q}+S(q)$ & $\begin{array}{l}\text { high; the variable is greater than or equal to the sum of the mean } \\
\text { and the standard deviation. Best potential group. }\end{array}$ \\
2 & $q_{i} \in\langle\underline{q}, \underline{q}+S(q))$ & $\begin{array}{l}\text { above average; the variable is less than the sum of the mean and the } \\
\text { standard deviation and greater than the mean. } \\
\text { below average; the variable is less than the mean and greater than } \\
\text { or equal to the difference between the mean and the standard deviation. } \\
\text { Average potential group. }\end{array}$ \\
4 & $q_{i} \in\langle\underline{q}-S(q), \underline{q}-S(q)$ & $\begin{array}{l}\text { low; the variable is less than the difference between the mean } \\
\text { and the standard deviation. Lowest potential group. }\end{array}$ \\
\hline
\end{tabular}

Source: developed by the author based on (Nowak, 1990, p. 93).

Table 4. Descriptive statistics of the typological groups

\begin{tabular}{crrrrrrr}
\hline Group & $\mathbf{2 0 1 6}$ & $\mathbf{2 0 1 7}$ & $\mathbf{2 0 1 8}$ & $\begin{array}{r}\mathbf{2 0 1 8 - 2 0 1 6} \\
\text { difference }\end{array}$ & $\begin{array}{r}\mathbf{2 0 1 7 - 2 0 1 6} \\
\text { changes }\end{array}$ & $\begin{array}{r}\mathbf{2 0 1 8 - 2 0 1 6} \\
\text { changes }\end{array}$ & $\begin{array}{r}\mathbf{2 0 1 8 - 2 0 1 6} \\
\text { changes }\end{array}$ \\
\hline 1 & 35 & 37 & 34 & -1 & 105.7 & 91.9 & 97.1 \\
2 & 85 & 81 & 74 & -11 & 95.3 & 91.4 & 87.1 \\
3 & 95 & 99 & 112 & 17 & 104.2 & 113.1 & 117.9 \\
4 & 40 & 38 & 35 & -5 & 95.0 & 92.1 & 87.5 \\
\hline Total & 255 & 255 & 255 & & & & \\
\hline
\end{tabular}

Source: developed by the author. 
Group 1 included between 34 and 37 cities. There were 24 cities that remained in this group throughout the period under consideration, of which 11 showed an increase in the value of the measure. Group 2 included between 85 and 74 cities, with a decreasing trend. There were 51 cities that remained in this group throughout the period under consideration, of which 33 showed an increase in the value of the measure. Group 3, the largest, was characterized by an increase in the number of its cities: from 95 to 112 . In this group, 73 cities remained in the group throughout the period under consideration, of which 39 cities showed an increase in the value of the measure. Group 4 was characterized by a decline in numbers from 40 to 35 cities. There were 24 cities that remained in this group throughout the period under consideration, of which 15 showed an increase in the value of the measure. The potential assessment was illustrated using a positioning matrix, where the coordinate on the horizontal axis reflected the level of the synthetic measure in 2018, while the coordinate on the vertical axis reflected the difference between the values of the synthetic indicator in 2016 and 2018. The 2018 value of the measure was the determinant for the cities' positions on the Weak-Strong axis (horizontal axis). The deviation difference between the 2018 and the 2016 indicator was the determinant for the cities' positions on the DeclineGrowth axis (vertical axis). This enabled the identification of processes that had contributed to the strengthening or weakening of the value of the synthetic measure in the cities analyzed (Sobczyk, 2015, p. 89). This is illustrated in Table 4.

120 cities decreased their potential within their group, whereas 135 cities increased their potential within their group. Out of the 255 cities, 83 showed synthetic measure variation leading to their reclassification to a different typological group. 37 of them saw an increase in the measure allowing them to move to the higher potential group. By far the most frequent progress was by one group, and there was only one case of progress occurring each year - first from group 3 to group 2, and then from group 2 to group 1.

The turnover (cities that did not change their position to the total number of cities in the group) within the individual groups was similar, although the trend was decreasing for three groups: 1, 2 and 4. In contrast, group 3 showed a $35 \%$ increase in turnover in 2018. The final element of the analysis was to compare the quantitative structure of the cities to the income structure within the different typological groups - Figure 2. It is very clear that in the cities classified in group 1, a smaller number of business taxpayers generated almost one third of the total income from this source. The opposite was true for group 4, whereas in almost $14 \%$ of the cities only $5 \%$ of income was generated by business taxpayers.

The structure of the taxpayers' income in the 255 cities analyzed varied. Income from employment relationships was the largest contributor, while the lowest income came from rental and lease and copyright.

More than $60 \%$ of the total income was generated under employment contracts by almost half of the taxpayers but, importantly, nearly $20 \%$ of the total income was generated from business activity by less than $7 \%$ of all taxable persons. At the same time, the increase in average income from business activity was the highest of all the sources over the period under consideration.

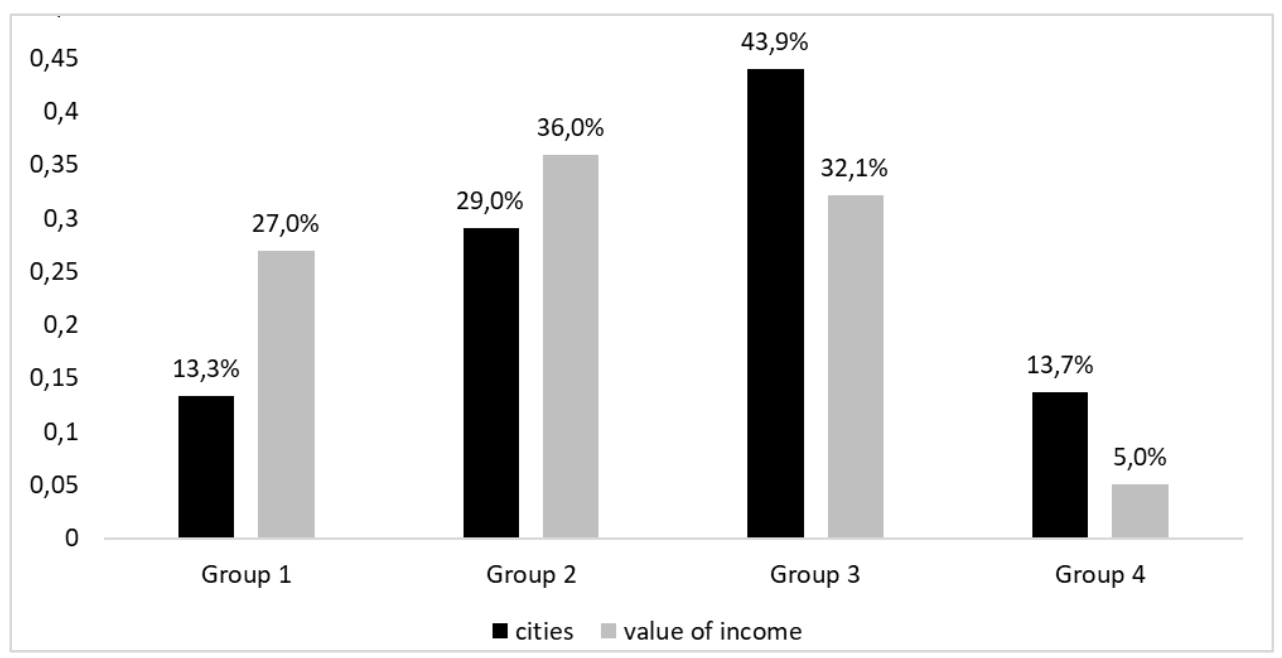

Figure 2. Comparison of the quantitative structure of the cities and the income structure between the different groups in 2018

Source: developed by the author. 


\section{Conclusion}

The potential of the financial streams generated by the economic activity of business taxpayers operating in the cities concerned varied, while the use of the multivariate analysis method allowed all 255 the cities to be divided into typological groups. The analysis of synthetic measure variation within the different typological groups allowed the identification of the regularities observed in the assessment of their potential in terms of the average income generated by business taxpayers.

Typological groups 1 and 2 are characterized by a relationship in which fewer units generate a higher income from business activity. A reverse relationship characterizes groups 3 and 4 .

Through the above study, the aim of the paper, which was to analyze and evaluate the local economic activities of the cities' residents, was achieved. In addition, the thesis that nonagricultural business activity was a highly efficient source of income, was verified positively.

The results obtained confirm the importance of the city's economic structure and its endogenous activities as endogenous factors of local development. In addition, they provide local authorities with knowledge of the nature of the impact of their economic policies when it comes to stimulating the socio-economic processes in the city. The analysis proposed herein therefore complements the urban socio-economic development theories cited in the first part of the paper. Given the above, it is justified that income from economic activities as sources of endogenous potential should be subject to detailed evaluations. However, this is dependent on both data availability and repeatability.

The research method applied in the study, and the results obtained, point to the necessity for research into endogenous urban and regional development factors. A direction is indicated herein for further research into the potential and efficiency of individual endogenous local development factors. And finally, it can be said that the analysis presented in the paper has allowed for an objective comparison between cities in terms of the efficiency of their residents' sources of income.

\section{References}

Bąkowski, A. Mażewska M. (eds.) (2018). Ośrodki Innowacji i Przedsiębiorczości w Polsce Raport 2018 [Innovation and Entrepreneurship Centers in Poland - Report 2018]. Warszawa: Stowarzyszenie Organizatorów Ośrodków Innowacji i Przedsiębiorczości w Polsce.
Pobrane z: http://www.sooipp.org.pl/static/files /raport_2018.pdf.

Budzeń, D. (2018). Ocena efektywności zarządzania długiem lokalnym w Polsce na przykładzie miast na prawach powiatu [Assessment of the Effectiveness of Local Debt Management in Poland on the Example of Cities with Poviat Rights]. Zielona Góra: Zeszyty Naukowe Polskiego Towarzystwa Ekonomicznego w Zielonej Górze, (9): 47-58.

Drobniak, A. (2016). Ekonomiczne koncepcje rozwoju w kontekście rewitalizacji miast studia przypadków [Economic Concepts of Development in the Context of Urban Regeneration - case studies]. Gospodarka lokalna w teorii i praktyce. Wrocław: Prace Naukowe Uniwersytetu Ekonomicznego we Wrocławiu, (432): 27-41.

Faller, F. (2009). Governing the Commons - The Evolution of Institutions for Collective Action by Elinor Ostrom, Seminar on Political Ecology. Bayreuth: University of Bayreuth.

Gruszecka-Tieśluk, A. (2013). Sieć Cittaslow strategią rozwoju małych miast w Polsce? [Cittaslow Network - a Strategy for the Development of Small Towns in Poland?] Nowoczesne instrumenty polityki rozwoju lokalnego - zastosowanie i efekty $w$ małych miastach, 144 (2): 383-393.

Heffner, K. (2016). Obszary wiejskie i małe miasta: czy lokalne centra są potrzebne współczesnej wsi? [Rural Areas and Small Towns: are local centers needed for today's small towns and villages?] Studia Ekonomiczne, (279): 11-24.

Hoornweg, D., Freire, M. (2013). Building sustainability in an urbanizing world A Partnership Report. Washington DC, World Bank.

Jewtuchowicz, A. (2016). Terytorium i terytorializacja w europejskiej polityce rozwoju regionalnego [Territory and Territorialisation in the European Regional Development Policy]. Studia prawno-ekonomiczne, XCVIII: 221-235.

Łapczyński, M. (2005). Wpływ aktywności mieszkańców na poziom życia w gminach woj. Małopolskiego [Influence of Inhabitants' Activity on Living Standards in the Communes of the Voivodeship of Małopolska]. In: (Ed. Wątroba, J.) Statystyka $i$ data mining $w$ badaniach naukowych. Warszawa: StatSoft Polska: 7989. Pobrane z: http://media.statsoft.nazwa.pl/ old_dnn/downloads/wplyw_aktywnosci.pdf.

Matczak, A., Szymańska, D. (2000). Baza ekonomiczna małych miast powiatowych w świetle pomiarów bezpośrednich. Studium porównawcze Brodnicy i Łasku [Direct Measurement of the Economic Base of Small Poviat Towns. A Comparative Study of Brodnica 
and Łask.] In: (Ed. Słodczyk, J.) Społeczne, gospodarcze i przestrzenne przeobrażenia miast [The Social, Economic and Spatial Transformation of Cities]. Opole: Wydawnictwo Uniwersytetu Opolskiego: 97-98.

Nowak, E. (1990). Metody taksonomiczne w klasyfikacji obiektów społeczno-gospodarczych [Taxonomic Methods in the Classification of Socioeconomic Objects]. Warszawa: Polskie Wydawnictwo Ekonomiczne.

Ostrom, E. (2000). Collective Action and the Evolution of Social Norms, Journal of Economic Perspectives, 14 (3): 137-158.

Pratt, A. (2008). Creative cities: The cultural industries and the creative class. Geografiska Annaler: Series B, Human Geography, 90 (2), 107-117. Doi: 10.1111/j.1468-0467.2008.00281.x.

Sadowy, K. (2019). Podstawowe zagadnienia ekonomiki miasta. Miasto - Gospodarka, Zarządzanie, Wyzwania. [The Primary Issues of City Economics. City - Economy, Management, Challenges]. Warszawa: Oficyna Wydawnicza SGH Szkoła Główna Handlowa w Warszawie: 13-49.

Sobczyk, A. (2015). Ocena potencjału demograficznego szczecińskiego obszaru metropoli- talnego z zastosowaniem zmiennej syntetycznej [An Assessment of the Demographic Potential of the Szczecin Metropolitan Area by Making Recourse to a Synthetic Variable]. Folia Pomeranae Universitatis Technologiae Stetinensis. Oeconomica, 317 (78): 1, 81-92.

Sokołowski, D. (2008). Baza ekonomiczna większych miast w Polsce w okresie transformacji systemowej [The Economic Base of the Larger Cities in Poland During the Transformation], Przegląd Geograficzny, 80 (2): 245-266.

Stimson, R., Stough, R., Salazar, M. (2005). Leadership and institutional factors in endogenous regional economic development, Investigaciones Regionales, Asociación Española de Ciencia Regional (7): 23-52.

Śleszyński, P. (2016). Delimitacja miast średnich tracących funkcje społeczno-gospodarcze [Delimitation of Medium-sized Cities that are Losing their Socio-economic Functions]. Warszawa: Instytut Geografii i Przestrzennego Zagospodarowania im. Stanisława Leszczyckiego PAN. 